\title{
Richard Norman
}

\section{New Public Management's Impact on Capital Cities new economic and employment challenges for Wellington}

The philosophy of New Public Management, which relies more on market solutions and less on government officials as initiators, has had particular impact for capital cities such as Wellington that are not also their country's dominant commercial centre. ${ }^{1}$ Wellington has been challenged to diversify away from government-related employment during the past 30 years. While it has had considerable success fostering tourism and software and film production, since 2008 growth in employment has been almost non-existent, contrasting with strong growth in Auckland, New Zealand's largest city and commercial centre. In 2013, John Key, prime minister in the country's centre-right government, triggered debate and local action with an offhand comment: 'even Wellington's dying ... all you have there is government, Victoria University and Weta Workshop'.

Richard Norman is head of the human resources and industrial relations specialisation at Victoria University's School of Management. Over the past three years, with support from 13 local government and the Ministry of Business, Innovation and Employment, he has been engaged with students and summer scholars in researching the changing nature of knowledge sector work in Wellington. ${ }^{2}$
In fact, Wellington is a relatively prosperous city at the heart of a region with a largely urban population of 480,000 which has New Zealand's highest average incomes, with nearly $50 \%$ of work in higher-skilled knowledge roles, contrasting with 33\% nationally (Wellington Regional Council, 2012, p.3). The anxiety in Wellington, which has prompted a rethinking of strategies for economic development, reflects growing international debate about the likely impact of technological change on work and responses needed from public organisations. The 20th anniversary conference of the International Public Management Network is a timely prompt to reflect on the leadership which might be expected from public administrators and managers during the early stages of a 'fourth industrial revolution' (Schwab, 2016).

Technologies seen as leading this revolution include mobile supercomputing, intelligent robots, selfdriving cars, neuro-technological brain enhancements and genetic editing. Klaus Schwab, founder of the World Economic 
Table 1: Changes in the distribution of population in New Zealand since the freeing of the markets in the 1980 s

\begin{tabular}{rrrrrr}
\hline Year & $\begin{array}{r}\text { New Zealand } \\
\text { population }\end{array}$ & Auckland & Wellington & $\begin{array}{r}\text { Auckland as percentage of } \\
\text { the national population }\end{array}$ & $\begin{array}{r}\text { Wellington as a } \\
\text { percentage of the } \\
\text { population }\end{array}$ \\
\hline 1984 & $3,264,000$ & 863,000 & 342,000 & 26.4 & 10.48 \\
2015 & $4,479,000$ & $1,500,000$ & 478,000 & 33.5 & 10.67 \\
\hline
\end{tabular}

Forum, fears the pace of change might be so great that organisations will be unable to adapt and governments will fail to employ and regulate new technologies to capture their benefits. Among results will be new security risks, and increasingly unequal and fragmented societies (ibid.). The scale of potential change in work
These margins put in context international, winner-takes-all economic pressures. But while digital technologies are global, people live and work locally and their local governments can expect to be at the front line of debate about how to respond. As a city with an already high proportion of knowledge-based

\section{Wellington's challenges are similar to those of many cities in an era of globalised markets, challenges which have led to 'winner takes all' successes ...}

was highlighted by a 2013 survey which concluded that nearly half of 700 United States employment classifications are at risk of being significantly altered by computerisation (Frey and Osborne, 2013). Millions of people with education and training which they thought would be work for a lifetime are likely to be 'not only unemployed but also obsolete' (Galbraith, 2014).

Letting nature take its course as occurred during the Industrial Revolution of the late 18th and early 19th centuries would be a 'dangerous gamble'. Those changes occurred over 50 years, with 'untold human suffering during an extended period of economic transformation' (Kaplan, 2015, p.15). The possible pace of change with the 'fourth industrial revolution' is illustrated by Kaplan, who contrasts revenue per employee of \$US855,000 for Amazon, the largest online retailer, with $\$ 213,000$ for Walmart, the largest bricks-and-mortar retailer; for each $\$ 1$ million in sales, Walmart employs about five people while Amazon employs slightly more than one person (ibid., p.139). work, and its capital city role, Wellington can expect to be at the forefront of this emerging public management challenge during the next decade.

\section{Relearning public leadership at a local level?} In 1996, when the International Public Management Network was founded, the internet was an emerging and unreliable technical wonder, not the commercial force it now is. Markets were favoured solutions for public services in the aftermath of the recent collapse of communism. New Zealand was an enthusiastic adopter of New Public Management ideas for reducing the size of government, contracting out services and using competition to reshape public services. These 'neo-liberal' views were theorised by economists during an era dominated by large public and private organisations that were strongly hierarchical and drew from the Second World War military experience of many of their leaders. New Public Management was assisted by one of the first 'miracles' of the era of personal computers, the spreadsheet, which, when linked with 'management by objectives', created a new era of rationalising, restructuring and managerialism by the numbers.

With a single debating chamber and a first-past-the-post electoral system, New Zealand politicians were able to introduce rapid and comprehensive change in the 1980s and early 1990s. New Zealand was the first nation to adopt private sector accounting methods throughout government. It adopted a comprehensive system for the delivery of public sector 'outputs' and gained an international reputation as either an exemplar of or cautionary tale about public sector change (Norman, 2003).

The neo-liberal theorising which influenced these system changes was summarised in April 2016 by the Guardian's George Monbiot.

Neoliberalism sees competition as the defining characteristic of human relations. It redefines citizens as consumers, whose democratic choices are best exercised by buying and selling, a process that rewards merit and punishes inefficiency. It maintains that 'the market' delivers benefits that could never be achieved by planning.

Attempts to limit competition are treated as inimical to liberty. Tax and regulation should be minimised, public services should be privatised. The organisation of labour and collective bargaining by trade unions are portrayed as market distortions that impede the formation of a natural hierarchy of winners and losers. Inequality is recast as virtuous: a reward for utility and a generator of wealth, which trickles down to enrich everyone. Efforts to create a more equal society are both counterproductive and morally corrosive. The market ensures that everyone gets what they deserve.

(Monbiot, 2016)

The emphasis on 'the market' has brought major changes for the role of capital cities. Prior to 1984, New Zealand had a tradition of strongly activist central government, starting with the opening up of new land during the 19th 
century, and redistributing wealth and providing social security in response to the depression of the 1930s. One result of the 'more market' policies since 1984 has been very limited economic growth in Wellington in contrast to Auckland. In that period Auckland has grown from having about one quarter of New Zealand's population to one third, while Wellington has remained at about 11\% (Table 1). 'More market' strategies adopted by central government, advised mostly by Wellington-based public servants, have created a new challenge for local and regional public organisations to consider how they might counter the pressures of 'winner takes all' market forces.

With the added pressure of technology change, leaders of local authorities have gained a new role, whether ready or not. While the market is international, 'place has replaced the industrial corporation as the key economic and social organising unit of our time' (Florida, 2012, p.188). Place is critical for economic development because jobs are increasingly dependent on entrepreneurs who can choose where to live and seek locations which provide 'high-quality amenities and experiences, an openness to diversity ... and the opportunity to validate their identities as creative people' (ibid., p.186). When each new high-tech job in a city can create five additional local jobs (Moretti, 2012, p.57), it is no longer sufficient for local authorities to focus overwhelmingly on the traditional roles of 'roads, rats and rates'. The ability to support infrastructure such as water and waste disposal, planning and parks is significantly affected by the economic health of the region. Wellington has adopted a 'creative capital' strategy to define its distinctiveness; but in doing so it is competing with at least 60 cities, 20 in Britain alone, which have sought to brand themselves as creative (Hollis, 2013, p.96).

Wellington bounced back from public sector cutbacks of the 1980s and 1990s with a period of activist public management which included major infrastructure projects such as the building of a new national museum, Te Papa (1998), and the Wellington Stadium

Table 2: Employment by sector, Wellington Region

\begin{tabular}{|c|c|c|c|c|c|c|c|}
\hline \multirow[b]{2}{*}{ Sector } & \multicolumn{4}{|c|}{ Employment Number FTEs } & \multicolumn{3}{|c|}{ \%pa Change } \\
\hline & 2005 & 2013 & 2014 & 2015 & 2014 & 2015 & $\begin{array}{r}2005 \text { to } \\
2015\end{array}$ \\
\hline Primary & 4,320 & 4,178 & 4,315 & 3,963 & 3.3 & -8.2 & -0.9 \\
\hline Manufacturing & 17,336 & 12,958 & 13,059 & 13,214 & 0.8 & 1.2 & -2.7 \\
\hline Construction & 14,833 & 16,600 & 15,841 & 17,154 & -4.6 & 8.3 & 1.5 \\
\hline Wholesale and Distribution & 17,118 & 16,308 & 16,622 & 15,939 & 1.9 & -4.1 & -0.7 \\
\hline Retail Trade and Service & 40,132 & 39,191 & 40,373 & 39,483 & 3.0 & -2.2 & -0.2 \\
\hline Business Services & 53,508 & 58,540 & 60,032 & 59,536 & 2.5 & -0.8 & 1.1 \\
\hline Arts and Recreation Services & 3,596 & 4,888 & 4,841 & 4,754 & -1.0 & -1.8 & 2.8 \\
\hline Social Services & 57,507 & 73,962 & 74,451 & 76,194 & 0.7 & 2.3 & 2.9 \\
\hline Wellington Regional Council & 208,351 & 226,626 & 229,533 & 230,237 & 1.3 & 0.3 & 1.0 \\
\hline New Zealand & $1,741,850$ & $1,883,050$ & $1,932,950$ & $1,976,617$ & 2.6 & 2.3 & 1.3 \\
\hline
\end{tabular}

Source: BERL Regional Datab ase, 2015

(2000) as part of the development of the waterfront alongside the central business district. Wellington-based film entrepreneurs have helped rebrand the city by gaining Hollywood backing for local production of films based on J.R.R. Tolkein's books The Lord of the Rings and The Hobbit. A capital city which New Zealanders tended to see as 'bureaucratic grey' in earlier times was in 2011 recommended by the Lonely Planet travel guide as 'the coolest little capital' and one of the top ten cities in the world to visit. Wellington was also helped by a buoyant economy and an expansionist left-ofcentre Labour government between 1999 and 2008, a period of central government activism which a centre-right National Party government has since 2008 sought to restrain.

Since 2008 Wellington has had almost no net employment growth (Table 2 ). The largest single local authority of the region, Wellington City Council, with 200,000 residents under its jurisdiction and a central business district which means it has about $60 \%$ of the rating base of the region, has again opted for an activist economic agenda. In June 2015 it opted to leverage the city's real estate assets and borrowing capacity to make available an additional $\$ 80$ million per year to invest in growth-oriented projects, with eight big development ideas as the strategic centre for action. Tourism, events management and economic development roles have been combined into a single agency, the Wellington Regional Economic Development Agency, with the goal that it take a broader approach to economic development to seek a way ahead from a period of relative decline. With the aim of encouraging economic growth, the council opted for a higher rates rise and borrowing and selling some assets in order to fund these initiatives:

- establish a tech hub in collaboration with the private sector with ICT start-ups;

- investigate an extension to the Wellington International Airport runway to allow for direct connections to Asia and to bring extra visitors, students and economic benefits;

- establish an international film museum to showcase talent and attract visitors and encourage them to stay longer;

- build a large-scale performance arena to fill a gap in the current offering and draw in larger concerts and more visitors;

- establish an urban development agency to support the creation of vibrant, mixed-use inner city neighbourhoods.

Concurrent with Wellington City Council efforts to take an activist approach to the local economy, the city's largest university, Victoria University of Wellington, adopted a strategic plan in August 2014 which proposes a doubling of student numbers, from 15,000 to 30,000 over 20 years. This plan also proposes that the university become more strongly a civic university, and tackle cross-disciplinary research 
themes of distinctive relevance to the region: advancing better government, cultivating creative capital, digital futures, design-led high-value manufacturing, and promoting sustainability. Two of Wellington's largest public organisations are therefore seeking ways to influence market forces that have shown the pulling power of larger cities in providing more diverse employment opportunities and larger local markets.

Wellington's challenges are similar
Cities are like natural ecosystems, 'not static entities but continually evolving creative commons that expand or shrink depending on the ingenuity of their residents' (Moretti, 2012, p.247). Human creative talent is now the most important part of a city's ecosystem, argues Richard Florida (2012). A city which seeks to attract and retain the people who are critical for its economy needs to consider: - what's there: the combination of the built environment and the natural

\section{Economic development increasingly based on knowledge and distinctive human capabilities involves very different economics from that based on large physical investments ...}

more like the manufacturing sector, with large independent firms wary of sharing information with other firms for fear of losing ideas. In Silicon Valley there was a more cooperative, interdependent environment in which many smaller firms worked through decentralised networks which prompted more innovation and different use of information and resources. Strong networks of

'weak ties' enable people to find work more easily and for cities with creative workers to be ideal laboratories of innovation: there are more people here, so the likelihood is that more ideas will bubble to the surface. It is not just the size of the population, however, but the density of the connections that matter' (Hollis, 2013, p.100). to those of many cities in an era of globalised markets, challenges which have led to 'winner takes all' successes such as Silicon Valley and Seattle, contrasted with the collapse of cities based on previous technologies, such as Detroit and the motor industry and Rochester, New York and Kodak film.

\section{Cities as sources of innovation and new} economic activity

In 1800, 3\% of the world's population lived in cities. Productivity gains made possible by coal, oil and electricity have seen the depopulation of rural areas during the 20th century. Cities now hold $54 \%$ of the world's population, and 100 cities account for a third of the world's economy (Ross, 2016, p.196).

As technology change and international trade during the past 30 years have spread the gains of the digital era unevenly, city-based political leaders have tended to be pragmatic interventionists. While neo-liberal ideas have dominated national debates in English-speaking countries, political leaders of cities have been prompted to seek pragmatic responses to changing economics which are locally visible through empty shops and social unrest. environment - a proper setting for pursuit of creative lives;

- who's there: the diverse kinds of people, interacting and providing cues that anyone can make a life in that community; and

- what's going on: the vibrancy of street life, cafe culture, arts, music and people engaging in outdoor activities - altogether a lot of active, exciting, creative endeavors.

The contribution of cities towards economic activity and innovation has been explained by the 'weak ties' they can provide, in contrast to smaller centres where everyone is likely to know everyone else (Granovetter, 1983). In New York's art world, for instance, 'your ability to get a new job is more likely dependent on a wide network of acquaintances who are plugged into a wider network of other acquaintances, further increasing your chance that someone knows someone who is willing to give you a job' (Currid, 2007). The importance of networks for creating new businesses was highlighted in a study by a political scientist and urban planner which contrasted the success of high technology enterprises in Northern California's Silicon Valley with the relative failure of Boston's Route 128 (Saxenian, 2006). In Boston, new companies worked
Changing work as a challenge for public sector leaders

Work has become so established as the dominant organising structure for developed societies that it is easy to overlook the extent to which it is a creation of city-based economies. Cities were first built around trade and manufacturing; now, knowledge-based work assisted by technology change is increasingly the force for economic development.

Such work is increasingly likely to involve cognitive and social skills. Cognitive skill is 'the ability to acquire knowledge, process information, and solve problems', while social skill is the 'capacities used to work with people to achieve goals'. These are 'more than just people skills', and 'include the capacity to bring the right people together on a project, persuasion, social perceptiveness, the ability to help develop other people, and a developed sense of empathy. These are the leadership skills that are needed to innovate, mobilize resources, build effective organizations, and launch new firms' (Florida, 2012, p.224).

Economic development increasingly based on knowledge and distinctive human capabilities involves very different economics from that based on large physical investments such as electricity supply or aluminium smelting, two 
major areas of New Zealand investment between the 1950s and 1980s. Peoplefocused skills that are least automatable are 'sensing the thoughts and feelings of others, working productively in groups ... and expressing ourselves with greater power than logic can ever achieve' (Colvin, 2015, p.3).

\section{Challenges facing the new Wellington} Regional Economic Development Agency

In 2014 the Wellington city and regional councils opted to merge tourism, events and economic development agencies, creating a larger agency with a total budget of about \$28 million, with \$8 million from trading and public funds contributed $80 \%$ by Wellington City and $20 \%$ through the regional council. Expectations for the new agency were set high in July 2015, with the board of the agency announcing the new mission that 'by 2025, Wellington will be the most prosperous, liveable and vibrant region in Australasia'. New agency chairman Peter Biggs said the bar was high but it could be done and there was no route to 'wimp out'. Wellington would not compete head to head with large Australian cities; comparisons were made with Tel Aviv in Israel and Manchester in England instead.

Among challenges the agency identified for the region were flat retail spending since 2011, a lack of confidence in the local economy, and a slowing of overall job growth despite employment growth in the public service resuming. There were skill shortages in key sectors, particularly information technology, and the region was not reaching its potential in terms of international visitors, particularly those from outside its traditional markets of Australia, the United States and Britain. The region was not getting its share of migrants and international students, and its distinctive arts and events positioning was being challenged, particularly by a united and increasingly confident Auckland.

The extent of this 'falling behind other parts of New Zealand' was highlighted in a report released in early 2016 for the Wellington Regional Council about economic trends. (Tables 2 and 3 have some of this data.) In the year to March 2015, GDP in the Wellington region increased by $1.3 \%$, compared with national growth of $3.2 \%$. Employment in the Wellington region grew by only $0.3 \%$ compared with $2.3 \%$ nationally. The agency described the strengths of the region as:

- a highly skilled and educated workforce;

- a strong knowledge-based services sector;

- world-renowned ICT, film, science and creative sectors;

- a mix of large multinationals and small and medium enterprises;

- the location for central government, funds allocated are less than 1000th the size of the regional GDP of \$26 billion. The Wellington Regional Economic Development Agency, in common with similar agencies, has as a priority the establishing of ways of leveraging its funds with a variety of partners.

The challenge for allocating local government support for economic development is highlighted by the comparative statistics on tourism and digital sector work in Wellington. The tourism sector contributes $2.9 \%$ of GDP to the region, compared with tourism throughout New Zealand which

\section{The knowledge-based sector of Wellington has moved beyond a stage of seeming almost 'accidental' as a series of support functions for long-established public sector and finance and insurance organisations.}

the public service and the diplomatic corps;

- a reputation as a leader in arts, culture and cuisine;

- a high-performing education sector, including three universities;

- a quality food and beverage offering, including innovative and export-led primary industries;

- the national centre for the expression and discovery of New Zealand's nationhood.

The newly reorganised agency faces the challenge of all public agencies that while politicians campaign in poetry, they 'govern in prose'. ${ }^{3}$

The extent of the gap between poetry and prose is evident in the dollars involved: a newly constructed agency with a rates-based budget of approximately $\$ 20$ million has a mandate to find ways of leveraging a regional economy of $\$ 25.6$ billion annual turnover and a workforce of 230,000. To tackle this task, the agency will have a staff of about 160 , with $75 \%$ of budget directed towards support for tourist promotions and events. The public makes up 3.8\% of GDP. Wellington's more dominant knowledge-based sectors are 'information, media and telecommunications', which contribute $6 \%$ of the local economy (compared with a New Zealand average of 3.2\%), and 'professional scientific and technical services' at $10.7 \%$ of the Wellington economy (compared with $7.3 \%$ nationally). Yet these sectors receive less funding than tourism, which can point to trackable numbers of visitor arrivals and spending patterns. The digital sector has had a multi-year run of unfilled job vacancies, at pay levels double those of tourism. The digital sector has been dispersed in its focus and growth has been so rapid that much of its focus has been on building individual businesses with local and international clients, leaving limited time for industry collaboration or local promotions.

\section{Leadership is needed for building a knowledge city}

As work becomes increasingly based on human innovation and relationship 
Table 3: Location Quotient 2015

\begin{tabular}{|c|c|c|c|}
\hline \multirow[t]{2}{*}{ Industry } & \multicolumn{2}{|c|}{ Wellington Region } & \multirow{2}{*}{$\begin{array}{r}\text { New Zealand } \\
\text { Share of total GDP }\end{array}$} \\
\hline & Location Quotient & Share of total GDP & \\
\hline Central Gov Admin, Defence \& Safety & 3.0 & $11.4 \%$ & $3.8 \%$ \\
\hline Petroleum \& Coal Product Manufacturing & 2.8 & $1.4 \%$ & $0.5 \%$ \\
\hline Telecomms, Internet \& Library Services & 1.9 & $4.4 \%$ & $2.3 \%$ \\
\hline Finance & 1.7 & $6.6 \%$ & $3.8 \%$ \\
\hline Printing & 1.7 & $0.5 \%$ & $0.3 \%$ \\
\hline Information Media Services & 1.6 & $1.4 \%$ & $0.9 \%$ \\
\hline Arts \& Recreation Services & 1.5 & $2.2 \%$ & $1.4 \%$ \\
\hline Professional, Scientific \& Tech Services & 1.5 & $11.2 \%$ & $7.7 \%$ \\
\hline Auxiliary Finance \& Insurance Services & 1.3 & $1.2 \%$ & $0.9 \%$ \\
\hline Other Services & 1.3 & $2.2 \%$ & $1.8 \%$ \\
\hline Insurance \& Superannuation Funds & 1.3 & $1.4 \%$ & $1.1 \%$ \\
\hline Electricity \& Gas Supply & 1.2 & $2.9 \%$ & $2.5 \%$ \\
\hline Local Government Administration & 1.1 & $0.6 \%$ & $0.5 \%$ \\
\hline Administrative \& Support Services & 1.0 & $2.1 \%$ & $2.1 \%$ \\
\hline Health Care \& Social Assistance & 1.0 & $5.9 \%$ & $6.1 \%$ \\
\hline Polymer Product \& Rubber Product Manu & 0.9 & $0.5 \%$ & $0.6 \%$ \\
\hline Rail, Water, Air \& Other Transport & 0.9 & $0.8 \%$ & $0.8 \%$ \\
\hline Water, Sewerage \& Waste Services & 0.9 & $0.4 \%$ & $0.5 \%$ \\
\hline Furniture \& Other Manufacturing & 0.9 & $0.3 \%$ & $0.3 \%$ \\
\hline Education \& Training & 0.9 & $3.8 \%$ & $4.3 \%$ \\
\hline Accommodation \& FoodServices & 0.9 & $1.8 \%$ & $2.1 \%$ \\
\hline Textile, Leather, Clothing, Footwear Manu & 0.8 & $0.2 \%$ & $0.3 \%$ \\
\hline Fruit, Cereal \& Other Food Product Manu & 0.8 & $0.7 \%$ & $0.9 \%$ \\
\hline Supermarket \& Specialised Food Retailing & 0.8 & $1.0 \%$ & $1.3 \%$ \\
\hline Property Operators \& Real Estate Services & 0.8 & $4.6 \%$ & $6.0 \%$ \\
\hline Other Store \& Non Store Retailing & 0.7 & $1.9 \%$ & $2.6 \%$ \\
\hline Pulp \& Paper Product Manufacturing & 0.7 & $0.2 \%$ & $0.3 \%$ \\
\hline Construction Services & 0.7 & $2.2 \%$ & $3.0 \%$ \\
\hline Fabricated Metal Product Manufacturing & 0.7 & $0.6 \%$ & $0.9 \%$ \\
\hline Postal, Courier \& WarehousingSenvices & 0.7 & $1.2 \%$ & $1.8 \%$ \\
\hline Road Transport & 0.7 & $0.9 \%$ & $1.4 \%$ \\
\hline Wholesale Trade & 0.6 & $3.4 \%$ & $5.3 \%$ \\
\hline Building Construction & 0.6 & $0.8 \%$ & $1.2 \%$ \\
\hline MotorVehicle, Parts \& Fuel Retailing & 0.6 & $0.4 \%$ & $0.7 \%$ \\
\hline Beverage \& Tobacco Product Manu & 0.6 & $0.5 \%$ & $0.9 \%$ \\
\hline Wood Product Manufacturing & 0.6 & $0.4 \%$ & $0.6 \%$ \\
\hline Rental \& Hiring Services & 0.6 & $0.7 \%$ & $1.1 \%$ \\
\hline Basic Chemical \& Chemical Product Manu & 0.6 & $0.3 \%$ & $0.6 \%$ \\
\hline Machinery \& Other Equipment Manu & 0.6 & $0.7 \%$ & $1.3 \%$ \\
\hline Non-Metallic Mineral Product Manu & 0.6 & $0.3 \%$ & $0.5 \%$ \\
\hline Meat \& Meat Product Manufacturing & 0.5 & $0.4 \%$ & $0.8 \%$ \\
\hline Transport Equipment Manufacturing & 0.5 & $0.2 \%$ & $0.5 \%$ \\
\hline Heavy \& Civil Engineering Construction & 0.5 & $0.9 \%$ & $1.8 \%$ \\
\hline Fishing \& Aquaculture & 0.5 & $0.1 \%$ & $0.1 \%$ \\
\hline Forestry \& Logging & 0.4 & $0.3 \%$ & $0.7 \%$ \\
\hline Primary Metal \& Metal Product Manu & 0.4 & $0.1 \%$ & $0.3 \%$ \\
\hline Poultry, Deer \& Other Livestock Farming & 0.4 & $0.1 \%$ & $0.1 \%$ \\
\hline Mining & 0.3 & $0.5 \%$ & $1.7 \%$ \\
\hline Sheep, Beef Cattle \& Grain Farming & 0.2 & $0.3 \%$ & $1.3 \%$ \\
\hline Dairy Product Manufacturing & 0.2 & $0.1 \%$ & $0.6 \%$ \\
\hline Horticulture \& FruitGrowing & 0.2 & $0.1 \%$ & $0.5 \%$ \\
\hline Agric Support Services \& Hunting & 0.2 & $0.1 \%$ & $0.7 \%$ \\
\hline Seafood Processing & 0.1 & $0.0 \%$ & $0.2 \%$ \\
\hline Dairy Cattle Farming & 0.1 & $0.3 \%$ & $2.6 \%$ \\
\hline
\end{tabular}

skills, as captured in the title of the book Humans are Underrated (Colvin, 2015), the core challenge of a city seeking to be activist about its economic future is to attract, retain and build distinctive skills. These are what Ulrich (2015) calls leadership skills that are required to navigate the industry conditions. Drawing on experiences of specialist investors, Ulrich summarises the industry and performance challenges facing any business. Industry favourableness includes such characteristics as growth potential, barriers to entry, competitiveness, social trends, customer opportunity and regulatory opportunities. The performance of a company will include financial results coupled with intangibles related to strategy, technological advantage, and capabilities such as speed to market, innovation and customer service. But the distinctive qualities for knowledge-based business development are likely to be the 'ability to set and execute strategy, to manage current and future talent, and to develop future leaders'.

The knowledge-based sector of Wellington has moved beyond a stage of seeming almost 'accidental' as a series of support functions for long-established public sector and finance and insurance organisations. The low-profile, privately owned Datacom, now New Zealand's largest information technology company, has grown significantly through gaining contracts in Australia. TradeMe, New Zealand's equivalent of the US trading site EBay, was a disruptive technology developed by a young entrepreneur at the expense of newspaper classified advertising. Xero, developer of cloudbased accounting software which puts a large part of the role of bookkeepers and accountants in the hands of end users, has yet to make a profit while it builds international business. These and hundreds of small start-ups in the digital sector have brought about a change in the shape of Wellington's economy as manufacturing has reduced. Many founders have emerged from large corporations and government agencies and are using their skills and entrepreneurship to create software 
products or services with internet-based, international markets.

This is the industry context which the new economic development agency is tackling. Questions which seem to this researcher to be most productive to pursue in more depth include:

- How can a city and a region with more than 500 digital sector vacancies best create such skills without relying too strongly on migration?

- How can tertiary education organisations best create 'employable' graduates during a period of rapid technology change without becoming 'trades' schools?

- How can public funds best be used to gain collaboration from the private sector to create new, high-value work, given perceptions that companies 'free-ride' on such money?

- How can the new Wellington Regional Economic Development Agency balance its role in supporting tourism and the creation of hightech work? ${ }^{4}$

\section{Conclusion}

Local governments can expect to face increasing expectations to provide leadership in tackling economic development, particularly in cities and smaller centres that are not buoyed by spending on construction that comes with population growth. Calls for public sector action on employment can be expected to increase as technology change affects increasing numbers of knowledge- and service-based jobs which can be converted into computer-controlled routines.

During the past 30 years the neoliberal approach to government has emphasised reducing the scale of government and its role in planning. The ideas of neo-liberalism were a disruptive 'technology' for the centralised and planning-intensive model of government of the early 1980s. Now that those ideas have become the 'new establishment', what forms of planning and activism can provide the most effective leverage for city leadership which refuses to accept a 'dying city' verdict?

If cities are to be generators of digitalera innovation, more activist 'ecosystems' of capability building and connectedness are needed. Wellington is a capital which has been significantly changed by New Zealand's adoption of 'more market' strategies at a national level. Wellington's current challenge is an example of an international pressure for local public sector leaders to explore new ways of leveraging limited public funds to create distinctive competitive advantage for the increasing pace of change of a 'fourth industrial revolution'

\footnotetext{
1 Ottawa and Canberra are other examples.

2 This article is an edited version of a presentation given at the 20th conference of the International Public Management Network, 1-3 June 2016, at St Gallen, Switzerland.

3 Attributed to Democratic governor of New York State, Mario Cuomo: https://en.wikiquote.org/wiki/Mario_Cuomo.

4 These are questions that are driving a next phase of research and the author would welcome input from others interested in these dilemmas for a period of digital disruption.
}

\section{References}

BERL (2016) The Wellington Region: situation analysis 2015:a snapshot, Business and Economic Research Ltd

Colvin, G. (2015) Humans are Underrated, New York: Penguin Random House

Currid, E. (2007) The Warhol Economy: how fashion, art and music drive New York City, Princeton: Princeton University Press

Florida, R. (2012) The Rise of the Creative Class Revisited, New York: Basic Books

Frey, C.B. and M.A. Osborne (2013) The Future of Employment: how susceptible are jobs to Computerisation?, Oxford: Oxford Martin School, University of Oxford, http://www.oxfordmartin.ox.ac.uk/ downloads/academic/The_Future_of_Employment.pdf

Galbraith, J. (2014) The End of Normal: the great crisis and the future of growth, New York: Simon and Schuster

Granovetter, M. (1983) 'The strength of weak ties: a network theory revisited', Sociological Theory, 1, pp.201-33

Hollis, L. (2013) Cities Are Good For You, London: Bloomsbury

Infometrics (2015) Wellington Annual Economic Profile, http://ecoprofile. infometrics.co.nz/Wellington\%20Region/PDFProfile

Kaplan, J. (2015) Humans Need Not Apply, New Haven and London: Yale University Press

Katz, B. and J. Bradley (2013) The Metropolitan Revolution, Washington, DC: Brookings Institution Press
Monbiot, G. (2016) 'Neoliberalism - the ideology at the root of all our problems', Guardian, 15 April , https://www.theguardian.com/ books/2016/apr/15/neoliberalism-ideology-problem-george-monbiot

Moretti, E. (2012) The New Geography of Jobs, New York: Mariner Books, Houghton Mifflin Harcourt

Norman, R. (2003) Obedient Servants: management freedoms and accountabilities in the New Zealand public sector, Wellington: Victoria University Press

Ross, A. (2016) The Industries of the Future, New York: Simon and Schuster

Saxenian, A. (2006) The New Argonauts: regional advantage in a global economy, Boston: Harvard University Press

Schwab, K. (2016) The Fourth Industrial Revolution, Geneva: World Economic Forum

Schwartz, B. (2015) Why We Work, New York: TED Books, Simon \& Shuster

Ulrich, D. (2015) The Leadership Capital Index: realizing the market value of leadership, San Francisco: Berrett-Koehler

Wellington Regional Council (2012) Wellington Regional Strategy 2012: growing a sustainable economy, Wellington: Wellington Regional Council 